Duška Meh

Univerza v Ljubljani

Medicinska fakulteta

Slovenija

meh.duska@gmail.com

Dejan Georgiev

Univerza v Ljubljani

Filozofska fakulteta

Slovenija

dejan.georgiev@gmail.com
DOI: https://doi.org/10.18485/slovenika.2020.6.1.7

UDK: 616.8-009.7:165.18]:316.7

Znanstveni članek

\title{
Bolečina kot pojav, razpet med telo, duševnost in sociokulturno okolje
}

\section{Povzetek}

Bolečina je večrazsežnostni pojav. Razumemo jo lahko, če upoštevamo vrsto dejavnikov, ki vplivajo nanjo, se medsebojno prepletajo in sodelujejo ter skupaj ustvarjajo enoten občutek, ki ga dojemamo vsak po svoje. Bolečina je namreč osebna izkušnja, ki je ne moremo deliti, jo pa z glasovi, besedami, kretnjami in vedénjem pokažemo tudi drugim. Ti jo lahko z obilico empatije vsaj okvirno spoznajo in razumejo. Ker se dogaja $v$ različnih zgodovinskih in sociokulturnih okoljih, je njeno dojemanje raznoliko in odvisno od vrste dejavnikov. Bolečina ne vpliva samo na posameznika, ki jo čuti, ampak tudi na družino, svojce in družbo kot celoto.

Ključne besede: bolečina, kulturne razlike, psihosocialni dejavniki, telo

\section{Uvod}

Bolečina je pojav, s katerim se srečujemo celo življenje. Neprijetno vsakdanjo izkušnjo poznamo skoraj vsi. Vedno je bila in je zavita $v$ tančico skrivnostnosti: doslej je še nismo uspeli dokončno spoznati in razložiti. Raziskovalcem ter strokovnjakom najrazličnejših ved predstavlja zaenkrat zanimiv, a še vedno neobvladljiv izziv. Laiki se pri iskanju odgovorov pogosto opirajo na vraže, pregovore in reke, »večne« bolj ali manj utemeljene resnice, ki so odvisne od okolja, kulture, navad 
in spoznanj $v$ družbi, $v$ kateri živijo, delajo in ustvarjajo. Tako npr. med ljudmi na sončni strani Alp krožijo mnoge, pogosto ne povsem veljavne »resnice« (Meh in Georgiev 2019), ki pa se najbrž bistveno ne razlikujejo od podobnih rekov v sosednjih državah. Bolj ko so si navade, običaji, kultura in zgodovina družbenih skupnosti podobni, bolj so podobni tudi njihovi dojemanje in s tem tudi pregovori o najrazličnejših pojmih in dogajanjih, med drugim tudi o bolečini. Ko se laiki srečajo $z$ vprašanji, ki so z za zdaj znanimi načini preučevanja še »ne-odgovorljiva« ali pa vsaj premalo poznana, prepuščajo razlage npr. vedeževalcem, magom in astrologom. Z mnogimi vprašanji se ukvarjamo znanstveniki in raziskovalci, v zadnjem času pa se veliko upov polaga v umetno inteligenco (Ahmed et al. 2017, Meh, Georgiev in Meh 2019, Pombo and Garcia 2019, Li, Wang and Wang 2019). Ta bo lahko izjemno pomagala, težko pa bo (če sploh bo) nadomestila človeka s človečnim pristopom.

$Z$ neprijetnimi in celo ogrožajočimi občutki se ukvarjamo različni strokovnjaki, npr. filozofi, zdravniki, psihologi, sociologi, informatiki. Glede na področje delovanja so vedno znova poskušali in še poskušamo bolečino čim bolje opredeliti in poudariti pomembne dejavnike, ki vplivajo na njeno dojemanje, razumevanje in obvladovanje.

\section{Razvoj vèdenja o bolečini}

Znanje o neprijetnem občutku se je razvijalo dolga stoletja (Perl 2007, Chen 2011, Qureshi et al. 2017). O bolečini so razmišljali različno. $V$ arhaičnih kulturah je prevladovalo prepričanje, da nastane zaradi poškodbe ali pa delovanja raznih neznanih elementov (tujkov), vdora demonov, čarobnih tekočin ali zlih duhov v človeško telo. Pomagali so lahko samo vrači, čarovniki in zdravilci, ki so tujek »izvlekli«, ali pa so uporabljali amulete, talismane, čarobne kipce, čarovniške obrede in rituale (Bonica 1991, Rodegra and Schreiber 2002). V starodavnem Egiptu so veljala podobna prepričanja, povezana s čarodejstvom in religijami, drugi in drugačni so bili le bogovi, čarodeji in različni pripomočki (El-Ansary 1989).Za druge starodavne kulture velja podobno, jih pa premalo poznamo in so predmet različnih antropoloških raziskav.

Dojemanje bolečine je bilo celostno. Biološke (fiziološke) in psihične značilnosti so intuitivno povezovali s pomenom občutka. Prevladovalo je in prevladuje v t. i. »vzhodnem« svetu (»orientalni« medicini). Dokumentirani začetki segajo $v$ obdobje pred našim štetjem (Zhu 2005, Veith 2015). Med prve znane zapise sodijo hieroglifi, ki so stari več kot 5500 let, označujejo obvladovanje bolečine (Halioua and Ziskind 2005) in so jih našli v Egiptu. $\vee$ kitajski medicinski literaturi (»Huang Di Nei Jing«) so npr. že pred 3000 leti opisali porušeno ravnotežje med yinom in yangom (izključujočima se nasprotjima, ki pa se dopolnjujeta), kar je prvi znan opis simptomov in znakov, ki jih v zahodni (»okcidentalni«) medicini pripisujemo vnetni in nociceptivni bolečini. Z mnogimi sta- 
rodavnimi kulturami $v$ različnih zgodovinskih obdobjih se podrobno ukvarjajo antropologi; vedno znova nas presenečajo nova odkritja, s katerimi bogatijo naše znanje požrtvovalni raziskovalci z včasih celo pustolovskimi podvigi (npr. novosti o majevski in maorski kulturi) (Dnevnik 2018, Delo 2020). Iz vesolja se s sodobno tehnologijo res vidi marsikaj, o odnosih in medčloveških spoznanjih pa vsaj zaenkrat največ izvejo in povejo ljudje $z$ dovolj radovednosti in empatije.

$\mathrm{V}$ »zahodnem svetu« se je vèdenje o bolečini razvijalo precej drugače. Ohranjeni zapisi iz 800 let pred našim štetjem so opisovali neprijetne občutke, najdemo pa jih v umetniških delih antične Grčije (Homerjevi Iliada in Odiseja) (Rey et al. 1995). Bolj »medicinsko usmerjeni« so zapisi Hipokrata in njegovih učencev iz 5. stoletja pred našim štetjem, kjer se je prvič pojavil izraz bolečina (Rey et al.1995). Dojemali so jo kot del splošnega bolnikovega stanja, in ne kot poseben simptom. Lajšali so jo z zdravilnimi učinkovinami, z ogrevanjem in s hlajenjem, $s$ kopanjem ali puščanjem krvi (torej pretežno $s$ fizikalnimi načini). Vprašanja bolečine še vedno niso razrešili in ljudi je še vedno zanimalo, od kod nenavadna »dogajanja« (skrivnostna bolečina) izvirajo, kako nastajajo in kaj jih povzroča. Iskanje odgovorov je zaposlovalo tako laike kot strokovnjake; prvi so se ozirali v mistiko in bogove, drugi pa so izvor telesnih in psihičnih dogajanj iskali v telesu. Aristotel (384-322 pred našim štetjem) kot najbolj znan mislec, ki se je ukvarjal tudi s človekovimi občutki (vid, sluh, voh, okus in bolečina), čustvi in mišljenji, si je za njihovo središče razlagal srce. Možgani naj bi ohlajali toploto, ki se sprosti ob delovanju srca. Njegovo razumevanje so v Antiki nadgrajevali mnogi drugi misleci (filozofi) in praktiki, kot so bili pred našim štetjem Pitagora (570-495) in Anaksagoras (500-428), po njem pa Galen (130-201). Slednji je prvi v razmišljanja o bolečini in drugih občutkih ponovno vpletel tudi možgane, kar pa ni bilo splošno sprejeto, in tako je Aristotelov pogled prevladoval mnoga stoletja. V Antiki in zgodnjem krščanstvu so se ideje o bolečini kot posledici zlih duhov pod vplivom mezopotamske in judovsko-hebrejske kulture spremenile; razlagali so jo kot kazen užaljenih božanstev zaradi predajanja grehom ali pa kot posledico božje sodbe.

V srednjem veku je bil med pomembnejšimi misleci Avicena (9801037), ki je poudarjal, da je bolečina drugačen občutek, kot so npr. dotik, hlad in toplota, in da ga moramo obravnavati ločeno/posebej. V zahodnem svetu se je postopoma razvijalo vedno bolj specializirano in zato ožje usmerjeno ter vsaj na nekaterih področjih razumljivejše in dojemljivejše znanje. Človeško telo so obravnavali kot stroj, v katerem so posamični deli v stalnem gibanju. Razlage bolečine so se usmerjale predvsem $v$ delovanje živčevja, saj so se razvijale mnoge naravoslovne vede, npr. anatomija, fiziologija, fizika, kemija. Humanistične vede so postale pretežno cerkvena domena, ki je $v$ tistem času postajala vedno bolj »edino pravo in veljavno« merilo presoje. 
V sedemnajstem stoletju je »oče moderne filozofije« Descartes (1596-1650) pustil neizbrisno sled, ki na mnogih področjih velja kot »resnica« še danes. Mnoge dogme ${ }^{1}$ še vedno slonijo na njegovih spoznanjih. Njegova filozofija temelji na neizpodbitnosti in nedvoumnosti dokazov, kar je eden od osnovnih znanstvenih postulatov. Med njimi je npr. tudi najzgodnejša fiziološka zasnova, ki razlaga občutljivost (senzoriko): dražljaje sprejmejo periferne živčne strukture (receptorji), nato potujejo do možganov, kjer nastane njihova slika (Slika 1, dostopno na: https://en.wikipedia.org/wiki/Pain_theories\#/media/File:Descartes-reflex.JPG). Descartes je ločil telo in duševnost. Možganom je pripisal pasivno vlogo (značilnosti dojetega občutka so odvisne izključno od perifernih struktur oz. od dogajanja na periferiji - vzdraženje določenega receptorja izzove določen občutek). Razlago danes imenujemo teorija specifične modalnosti, ki je prevladovala cèlo 19 . stoletje. $V$ poznejši teoriji vzorcev je vloga možganov ostala nespremenjena. Značilnosti občutka so odvisne od vzorca dražljaja; za določen občutek je potrebno vzdraženje natančnega vzorca receptorjev. Zgodovinski pregled so opisali v več člankih (Melzack and Wall 1962, Perl 2007, Meh in Georgiev 2013). V nobeni od opisanih razlag še ni bilo prostora za psihološki vidik razumevanja bolečine (Melzack 1993).

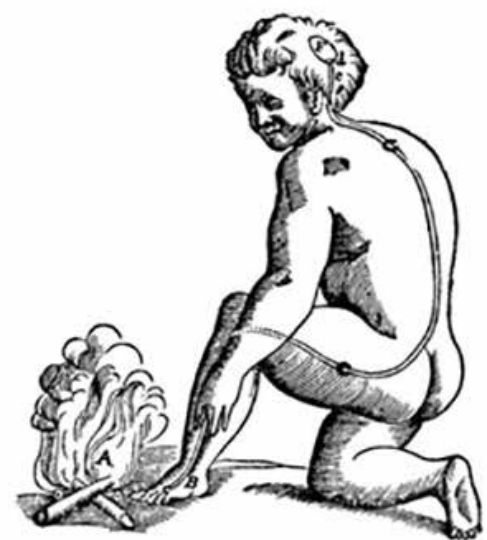

Slika 1. Descartesova ponazoritev potovanja bolečinskega impulza od mesta draženja do sprejemnega mesta v osrednjem živčevju (Descartes 1972).

\section{Sodobno dojemanje bolečine (20. in 21 . stoletje)}

Razlaganje in razumevanje bolečine kot samo eno-razsežnostnega dogajanja ne more zajeti kompleksnosti občutka, ki odseva različne vidike dogajanja v človeku in okoli njega. Celosten pogled na dojemanje bolečine in drugih občutkov omogočata teoriji vrat in živčnega (nevronskega) mrežja (nevromatriksa) (Melzack and Wall 1965, Melzack

\footnotetext{
${ }^{1} »$ Trditev, načelo, ki temelji na avtoriteti, ne na znanstvenih dokazih« (Černivec et al. 2020).
} 
1996, 2001, 2005). S teorijo vrat sta Melzack in Wall razložila dinamične procese, ki sodelujejo pri sprejemu, potovanju in vzbujanju aktivnosti v različnih delih perifernega in osrednjega živčevja ter $v$ psihičnih in kognitivnih procesih (tabela 1). Boleči dražljaji delujejo na receptorje, sprejemna mesta, in povzročijo nastanek bolečinskih živčnih impulzov, ki se med potovanjem od sprejemnega mesta do najvišjih središč (po živčnih vlaknih A-delta in C) preoblikujejo (slika 2). O vsem je napisano ogromno raziskav, naša skupina pa je pripravila didaktično primerni predstavitvi (Meh in Georgiev 2013, Meh in Georgiev 2021, v tisku). Bolečinske živčne impulze zavirajo drugi impulzi, ki jih izzovejo neboleči dražljaji in do hrbtenjače prispejo po debelih dovodnih živčnih vlaknih (A-alfa in A-beta). Poleg tega pa na bolečinske živčne impulze pomembno vpliva tudi delovanje celic osrednjega živčevja (osrednji nadzor), ki določajo aktivnosti $v$ descendentnih (navzdol usmerjenih) vlaknih iz ustreznih delov osrednjega živčevja. Mesto, kjer se aktivnosti iz periferije in osrednjih središč seštevajo, so živčni gangliji ob hrbtenjači (celice G) in $v$ hrbtenjači (celice T), oboje deli živčnega mrežja (slika 2) (Melzack and Wall 1965; predstavljeno tudi v: Meh in Georgiev 2013, Meh in Georgiev 2021, v tisku).

\begin{tabular}{|c|c|}
\hline Odpiranje vrat & Zapiranje vrat \\
\hline \multicolumn{2}{|l|}{ Fiziološki dejavniki } \\
\hline $\begin{array}{l}\text { - poškodbe } \\
\text { - napačen motorični vzorec } \\
\text { - nedejavnost ali prekomerno } \\
\text { utrujanje }\end{array}$ & $\begin{array}{l}\text { - kratkotrajna uporaba } \\
\text { protibolečinskih zdravil } \\
\text { - sprostitev } \\
\text { - ustrezna stopnja aktivnosti }\end{array}$ \\
\hline \multicolumn{2}{|l|}{ Psihični dejavniki } \\
\hline $\begin{array}{l}\text { - slabo razpoloženje } \\
\text { - jeza ali bes } \\
\text { - tesnobnost ali napetost } \\
\text { - skrbi }\end{array}$ & $\begin{array}{l}\text { - pozitivna pričakovanja } \\
\text { - osredotočanje na pozitivna } \\
\text { čustva } \\
\text { - pravilno premagovanje stresa } \\
\text { - izogibanje prekomerni } \\
\text { zaskrbljenosti }\end{array}$ \\
\hline \multicolumn{2}{|l|}{ Kognitivni dejavniki } \\
\hline $\begin{array}{l}\text { - osredotočenost na bolečino } \\
\text { - nezanimanje za zunanja } \\
\text { dogajanja } \\
\text { negativne misli, povezane z } \\
\text { obvladovanjem bolečine }\end{array}$ & $\begin{array}{l}\text { - odvračanje pozornosti od } \\
\text { bolečine } \\
\text { - povečanje družabnih } \\
\text { aktivnosti } \\
\text { - prepričanje, da je bolečina } \\
\text { obvladljiva }\end{array}$ \\
\hline
\end{tabular}

Tabela 1. Dejavniki, ki odpirajo in zapirajo vrata. 


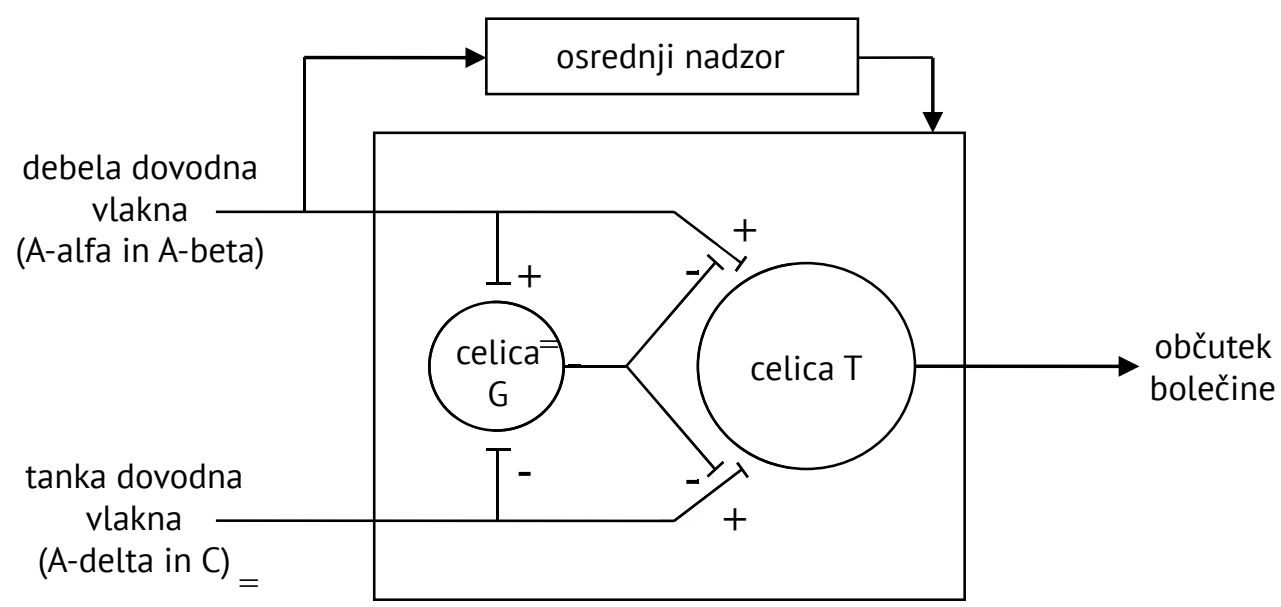

Slika 2. Teorija vrat razlaga povezanost in odvisnost aktivnosti v različnih vlaknih v perifernem živčevju ter medsebojni vpliv osrednjih in perifernih dejavnosti (Melzack and Wall 1965). Celica G - celica v želatinozni snovi, celica T - prenosna celica.

S teorijo živčnega (nevronskega) mrežja (nevromatriksa) je Melzack pojasnil vlogo osrednjega nadzora v teoriji vrat, tj. kako se v dojemanje občutkov, npr. bolečine, vključujejo drugi in drugačni procesi, kot so npr. psihični in socialni. Bolečina kot sestavljen in zelo dinamičen občutek je namreč odvisna od delovanja različnih središč v osrednjem živčevju. Deli možganske skorje, ki se aktivirajo pri določenem vidiku bolečine, so različni, saj za bolečino ne obstaja natančno anatomsko in fiziološko določeno središče, kakor jih lahko opredelimo za druge občutke (npr.zatilni del možganov za vid). Čustvena komponenta bolečine je npr. povezana $z$ aktivnostjo $v$ limbičnem sistemu in $v$ inzuli (Uddin 2015), pomen bolečine je npr. povezan $z$ aktivnostjo $v$ predčelnem delu možganov (Simons, Elman and Borsook 2014), prostorska opredelitev bolečine je npr. povezana $z$ aktivnostjo $v$ somatosenzoričnem delu možganske skorje (Haggard, lannetti and Longo 2013) in še drugi vidiki bolečine so povezani z drugimi središči v osrednjem živčevju (Basbaum and Bushnell 2008).

Po Melzackovi razlagi je dojemanje bolečine posledica dogajanja $\vee$ delu osrednjega živčevja, v velikih možganih. Izzvane aktivnosti nastanejo ali spontano ali po dotoku senzoričnih impulzov (tako bolečinskih kot nebolečinskih). V živčno mrežje prispejo iz receptorjev, ki so lahko specifični (npr. vidni, slušni) ali nespecifični (npr. kožni, visceralni), iz prej naštetih različnih delov aktivirane možganske skorje, iz notranjih živčnih zaviralnih ali spodbujevalnih procesov ter iz telesu lastnih procesov za uravnavanje npr. stresa (npr. endokrini, imunski, avtonomni) ali drugih nujnih stanj (Melzack 1999, Schulkin 2004). Spontane aktivnosti nastanejo z aktivacijo živčnega mrežja (nevromatriksa). 
Živčno mrežje za bolečino sestavljajo vse živčne poti, ki so vpletene $\checkmark$ oblikovanje odgovora na bolečinski dražljaj. Običajno so živčne poti zelo natančno opredeljene (so specifične), kar pomeni, da natančno poznamo receptorje, ki izzovejo potovanje bolečinskih impulzov, in natančno poznamo poti, po katerih impulzi prispejo do različnih delov osrednjega živčevja (specifične bolečinske poti). Zaradi podatkov iz sodobnih preiskavnih aparatov tudi natančno vemo, katera središča $v$ osrednjem živčevju bolečinski impulzi aktivirajo in so vpletena v dojemanje neprijetnega občutka. Vse te anatomske in fiziološke elemente imenujemo živčno mrežje in je za različne tipe bolečine različno, vedno pa natančno opredeljeno. Oblikuje specifične živčne zapise (živčne sledi), ki izzovejo specifično zaznavo, občutek in/ali specifičen telesni odziv. Fizikalne značilnosti živčnega zapisa določi npr. seštevek električnih parametrov v impulzih, ki so pripotovali po živčnem mrežju in ga izzvali. Dojet občutek ima tako fizikalne kot kakovostne in druge značilnosti, prispele po specifičnem živčnem mrežju. Najočitnejša je velikost oz. moč, o večini drugih pa nam poroča posameznik, $v$ katerem poteka vrsta na zunaj nevidnih procesov. Opazimo pa seveda vedénje, ki ga izzovejo različni procesi, ko se "prevedejo« v na zunaj vidne odzive.

Pri bolezenskih stanjih, npr. pri kroničnih bolečinah, specifičnosti ni več, saj lahko bolečino izzovejo tudi receptorji na neznačilnih (pogosto sosednjih) anatomskih področjih in v nebolečinskih živčnih vlaknih, ki običajno niso vpletena $v$ dojemanje bolečine. Proces je lahko obsežnejši; možna je osrednja senzitizacija in aktivacija nespecifičnih delov osrednjega živčevja (Moseley et al. 2012), pa tudi periferna senzitizacija (Arendt-Nielsen et al. 2018). Oblikuje se nespecifičen živčni zapis oz. živčna sled. Vključuje tudi nespecifične živčne poti, zaradi katerih je izzvan odziv ali večji ali manjši od specifičnega. Živčni zapis je količinsko zelo odvisen od značilnosti električnih parametrov $v$ impulzih, ki pripotujejo po nespecifičnem živčnem mrežju, in so lahko ali spodbujevalni (facilitacija) ali zaviralni (inhibicija).

Novonastali živčni zapisi (živčne sledi) so shranjeni v predhodno neaktivnih delih možganske skorje. Sestavlja jih cela paleta živčnih zapisov, ki so nastali tudi po delovanju dovodnih (npr. bolečinskih) dražljajev. Večkrat ko na telo delujejo novi dovodni dražljaji, več imamo živčnih zapisov, vsaj enkrat aktivirane možganske skorje in bogatejšo zakladnico odzivov, ki jih telo uporabi kot vzorec ravnanja pri hitrem in uspešnem obvladovanju možno nevarnih stanj (npr. okužb, stresov). Bolečina je eno izmed življenjsko pomembnih dogajanj, ki so pogosto odvisna od hitrosti odziva, ta pa tudi od obsežnosti shranjenih ustreznih živčnih zapisov. Če smo se $z$ določenim dražljajem že kdaj srečali, imamo vzorec zapisa že shranjen v paleti bolečinskih odzivov in je lahko izzvana aktivnost zelo hitra ter kot del živčnega zapisa uspešno vstopa v dogajanje. Če je samo podoben arhiviranemu zapisu, je akti- 
vacija počasnejša, še počasneje pa se vse dogaja, če je dražljaj povsem nov in se mora ustrezen odziv še oblikovati (Meh in Georgiev 2021, v tisku).

\section{Bolečina kot fiziološki (biološki), psihološki in sociokulturni izziv}

Bolečina kot vsakdanje večrazsežnostno dogajanje je po eni strani telesni pojav, ki nas opozarja ali, če ga ne upoštevamo ali celo spregledamo, svari zaradi neprijetnih ali možno nevarnih dogajanj $v$ nas ali $v$ naši okolici, po drugi strani pa je psihološki, sociološki, kulturni, ekonomski, informacijski itd. proces z različnimi značilnostmi.

O opredeljevanju neprijetnega in včasih celo ogrožajočega občutka so vedno veliko razpravljali. Avtorja opozarjava na sprejete in vsaj v zahodni, konvencionalni medicini splošno veljavne opredelitve, ki po najinem mnenju povzemajo najpomembnejše danes znane značilnosti osebnega občutka. Bolečina »obstaja« namreč samo takrat, kadar posameznik poroča o njej (Large 1996), jo je pa treba vedno upoštevati in sprejemati kot dejanskost (resnično dogajanje). Na to premnogokrat pozabljajo vsi, ki značilnosti neprijetnega občutka, ko postane obremenjujoč in povzroča trpljenje (Schleifer 2014), na srečo poznajo samo iz bogatega nabora znanja, ne pa iz lastnih izkušenj. Na splošno je najbolj znana in sprejeta opredelitev Mednarodnega združenja za preučevanje bolečine (IASP - International association for the study of pain) - »Bolečina je neprijetna senzorna in čustvena izkušnja, povezana z dejansko ali možno okvaro tkiva, ali pa se kot takšna vsaj kaže« (Merskey et al. 2012). Pomembna je opredelitev, ki poudarja in vključuje psihično plat bolečine. Meniva, da je bolj povedna za celostno razumevanje občutka: »Bolečina je dojemanje $v$ telesu, ki vsebuje (a) telesne zaznave s kakovostmi, o katerih poročajo npr. pri telesni okvari, (b) občutek grožnje, povezan s temi zaznavami, in (c) občutek nelagodja/ neprijetnosti ali drugih negativnih čustev, ki temeljijo na tej grozeči izkušnji« (Price and Bushnell 2004).

Bolečino lahko razdelimo po različnih merilih. $\vee$ konvencionalni zahodni medicini je najpogosteje veljavna in »zveličavna« časovna razdelitev, ki upošteva čas njenega pojavljanja in trajanje. Lahko je akutna ali kronična, periferna ali osrednja, telesna ali psihična. Če bi upoštevali še druge značilnosti, bi bile razdelitve drugačne. Kronične telesne bolečine zelo podrobno preučujejo in so jih zaradi učinkovitejšega razvrščanja uvrstili v poseben sistem (Merskey and Bogduk 2012). Podobnih razvrstitev drugih oblik bolečine pri svojem delu še nisva našla. Medicina se zaradi težav, ki jih ljudem povzroča neprijeten in ogrožajoč občutek, z njim zelo veliko, a po mnenju mnogih, ki smo zelo vpeti v dogajanje, še premalo ukvarja. Za obvladovanje kronične bolečine porabimo več sredstev kot za vrsto drugih bolezni skupaj (Leadley 
et al. 2012, Gaskin and Richard 2012, 2011). Kljub temu je še vedno niso uvrstili $v$ najnovejšo, deseto mednarodno razvrstitev bolezni in sorodnih zdravstvenih problemov (Moravec Berger in Kovačič 2005). Morda delno tudi zato drugih delov družbenih skupnosti ne zmore ali zna pritegniti v skupno prizadevanje za njeno obvladovanje.

O bolečini, ki je večrazsežnostno dogajanje, se pogovarjamo na različnih ravneh. Laiki jo poznajo kot vsakdanji občutek, ki je neprijeten in nas pogosto prestraši. Odzovemo se tako, kot nam »narekuje« prirojen mehanizem, ki smo ga »prinesli« na svet ali kot smo se naučili v okolju, $v$ katerem trenutno smo. Preprosto si bolečino razlagamo kot biološko dogajanje, kjer dražljaj potuje po perifernih živcih ali drugih živčnih strukturah in »nekje« izzove neprijeten občutek in odziv. V resnici ni povsem tako; v prej opisani teoriji vrat so natančno razložili, od kod in kam ter predvsem kako prenašajo impulzi informacijo o neprijetnem dogajanju. Od perifernega dražljaja potujejo do središč, ki so večinoma $v$ različnih delih velikih možganov. S teorijo živčnega mrežja (nevromatriksa) so raziskovalci bolj ali manj uspešno in razumljivo razlagali, kako se vsi impulzi medsebojno povezujejo in skladno z informacijami, ki so jih sprožile in tudi določile, na natančno opredeljen način učinkujejo. Izzovejo občutek in/ali ravnanje (vedénje).

Vedno je treba poznati in upoštevati nekaj osnovnih značilnosti dogajanja. Bolečina je eden od občutkov, na katerega smo zaradi vrste razlogov posebej pozorni (lannetti and Mouraux 2010). Je neprijeten, včasih nas opozarja celo na možno ogrožajoče dogajanje v nas ali okoli nas; če je le možno, se mu vsaj poskusimo izogniti ali mu nasprotovati, se »spopasti $\mathrm{z}$ njim. Je posledica zaznave (angl. sensation), prepoznave (angl. recognition) in spoznave oz. dojemanja (angl. perception) (Gatchel et al. 2007, Meh in Georgiev 2013, Basbaum and Jessell 2014) (tabela 2).

\begin{tabular}{|c|c|}
\hline $\begin{array}{l}\text { zaznavanje } \\
\text { (angl. sensation) }\end{array}$ & $\begin{array}{l}\text { dražljaj (npr. zbodljaj) izzove fiziološke } \\
\text { spremembe v telesu }\end{array}$ \\
\hline $\begin{array}{l}\text { spoznavanje oz. } \\
\text { dojemanje } \\
\text { (angl. perception) }\end{array}$ & $\begin{array}{l}\text { dražljaja se zavemo, ga kognitivno } \\
\text { »obdelamo« (npr. zavemo se, da se je nekaj } \\
\text { zgodilo, dogaja pa se istočasno z zaznavo) }\end{array}$ \\
\hline $\begin{array}{l}\text { prepoznavanje } \\
\text { (angl. recognition) }\end{array}$ & $\begin{array}{l}\text { v kognitivnem procesu ugotovimo, kakšen je } \\
\text { dražljaj (ga prepoznamo) }\end{array}$ \\
\hline
\end{tabular}

Tabela 2. Razlaga pojmov, vpletenih v razumevanje neprijetnega občutka, bolečine (Meh in Georgiev 2013).

Kadar so spremembe le telesne, tj. fiziološke (biološke), vplivajo le na fizikalne lastnosti impulza in odziva, ki ga imenujemo zaznavanje, proces pa nocicepcija (Loeser and Treede 2008). Bolečina nikoli 
ni izključno biološko dogajanje, vedno je vpletena vrsta drugih procesov, najpogosteje fizikalne dopolnjujejo ali celo določajo psihološki (McGrath 1994), opredelimo pa jih s posebno preiskavo in natančno določenim protokolom (Meh, Meh in Georgiev 2016b). Bolečine se moramo zavedati in prav kognitivni dejavniki so pri dojemanju (spoznavanju) ter prepoznavanju neprijetnega občutka bistveni (Moriarty and Finn 2014). Če upoštevamo danes veljavne opredelitve bolečine (Merskey et al. 2012), smemo o bolečini govoriti šele in samo takrat, ko smo budni, se zavedamo, smo se sposobni odločati in o bolečini poročati, kar je mogoče s posebno preiskavo tudi preveriti in dokumentirati (Melzack and Torgerson 1971, Meh in Georgiev 2013, Meh, Meh in Georgiev 2016a). Šele ko bolečina postane »vidna«, ko o njej poročamo ali jo z mimiko, gibi, s položajem telesa, z vedénjem itd. prikažemo tudi navzven, ožji in širši socialni in drugi družbeni okolici, postane tudi bolj ali manj pomemben družben pojav. Značilnosti različnih okolij, med katerimi je zelo pomembno sociokulturno, vplivajo na čustva, dojemanje, vedénje in prepričanja vseh posameznikov. Med njimi so tako posamezniki, ki bolečino doživljajo, kot njihova ožja in širša socialna okolica, ki jo z empatijo spremlja, ter strokovnjaki, ki se ukvarjajo z njenim prepoznavanjem in obvladovanjem. Posameznik lahko čuti bolečino krajši ali daljši čas, ali pa celo živi z dolgotrajno nezdravljeno ali neobvladljivo bolečino. Socialna okolica mu nudi tudi od sociokulturnega okolja odvisno svetovanje, podporo in pomoč. Dojemanje bolečine pri posamezniku z bolečino je odvisno od zanj sprejemljivih vzorcev obnašanja, ki so v družbi običajni ali celo »nagrajeni« (z večjo pozornostjo, pripravljenostjo za nudenje pomoči, z usmiljenjem ipd.). V družbi so tudi strokovnjaki, ki odločajo o uradnem (konvencionalnem) obvladovanju neprijetnega osebnega občutka. Rešujejo stiske ljudi z bolečino, ob tem pa so občasno v stiski tudi sami, saj je poklicna zavezanost $k$ doktrinarnim merilom včasih omejujoča (Berghaus and Albreht 2020).

Posameznik torej na osnovi meril, ki veljajo $v$ njegovi socialni in kulturni okolici, ugotovi, ali je njegovo dojemanje bolečine »normalno« (sodi v okvir običajnega dojemanja v njegovi sociokulturni okolici) ali »nenormalno« ( $v$ katerikoli značilnosti odstopa od vedénja njegove okolice). Odloči se, ali ga bo pokazal ali potlačil. Glede na odločitev poišče oz. sprejme pomoč in pričakuje podporo ožjega in širšega socialnega ter tudi strokovnega okolja.V slednjem je odvisen od strokovne opredelitve njegove težave, od diagnoze. Pri njej konvencionalno izobraženi strokovnjaki upoštevajo fiziološke (biološke) dejavnike in vidike. Ob tem prav zaradi »enorazsežnostne« (v konvencionalni medicini tradicionalno bolj ali celo zgolj naravoslovne) predstave prevečkrat pozabljajo, da je bolečina precej več kot »odbirek« in »zbirek« količinskih vrednosti mnogih parametrov. Spregledajo psihološke procese in dejavnike, ki so za celostno dojemanje in prepoznavanje bolečine včasih odločilni. Ker zanemarjajo družboslovne dosežke in spoznanja, 
so hoté ali celo nevedé »slepi« za sociokulturne dejavnike, zelo odvisne od družbene sredine, $v$ kateri je trenutno posameznik. V določenih razmerah so občasno $v$ bistvenem nasprotju s posameznikovim "prirojenim« odzivom (vedénjem); ta je prisiljen izbrati med spoznanjem, kakršno je zanj osebno »normalno in sprejemljivo«, ter priučenim odzivom, kakršnega od njega zahteva npr. doktrina (in kar včasih bolj ali manj upravičeno in včasih opravičljivo tudi naredi). Poročanje o bolečini se tako lahko občasno bistveno spremeni predvsem pri posameznikih, ki niso povsem prepričani v svoje znanje in svoj prav.

\section{Bolečina v Evropski uniji in Sloveniji}

Kot sva že omenila, je največ o bolečini mogoče prebrati $v$ medicinski literaturi. Še vedno ali celo vedno bolj je usmerjena $v$ zbiranje podatkov, ki so ustrezni za rokovanje s pomočjo strojne opreme ali celo umetne inteligence. Čeprav je tak pristop trenutno zelo privlačen, je predvsem za podatke o različnih notranjih procesih še neuporaben (Price in Barrell 2012). Umetna inteligenca bo kompleksen večrazsežnostni občutek celostno prikazala šele, ko jo bomo opremili z ustreznimi algoritmi. Doslej še niso bili dovolj uspešni (Topol 2019, Hu et al. 2019, Georgiev in Meh 2019).

Dokler bo pogled na bolečino enodimenzionalen (pretežno biološki oz. fiziološki), bodo možne samo raziskave, kakršna je bila zelo obsežna raziskava o pogostosti in posledicah bolečin v Evropski uniji (Fricker 2003, Breivik et al. 2006). Pretežno temelji na merljivih podatkih. Slovenija vanjo ni bila vključena, zato so podatke v Sloveniji zbrali v poznejši raziskavi (Pirc in Cesar Komar 2007). Izkazalo se je, da je bolečina razmeroma pogosta težava ljudi med 18 . in 75 . letom starosti (povprečna starost anketirancev $s$ kronično bolečino je bila manj kot 50 let). Vsaj občasne bolečine je imelo več kot $65 \%$ anketiranih, najpogostejša pa je bila bolečina pri ženskah, starejših od 60 let. Pogostejša je bila med manj izobraženimi prebivalci (z osnovnošolsko izobrazbo ali celo brez nje). Pojavljala se je različno pogosto, razlogi zanjo pa so bili različni. Najpogostejše so bile bolečine $v$ križu/hrbtenici, okončinah, sklepih, sledijo glavoboli, bolečine $v$ trebuhu, mišicah in na nekaterih redkejših mestih. Pri polovici anketiranih je bolečina trajala pet let in več, pri petini dve do pet let, pri tretjini pa manj kot dve leti. Povprečna jakost bolečine, ocenjena z vidno analogno lestvico, je bila 7.3, o nevzdržni bolečini je poročala petina anketiranih. Večina bolečin je bila nerakavih.

$\checkmark$ slovenski raziskavi so, podobno kot $v$ evropski, ocenili tudi vpliv bolečine na življenje in delo ljudi, ki jih neprijeten občutek obremenjuje. Spraševali so tudi o obvladovanju neprijetnega občutka. Rezultati obeh raziskav so bili primerljivi in podobno bi bilo smiselno opraviti tudi $\vee$ Srbiji. Tak tip raziskav je zelo pomemben, a malo pove o po- 
sameznikovem doživljanju bolečine in o vsem, kar spremeni njeno dojemanje.

\section{Pogled v prihodnost (namesto sklepa)}

$\mathrm{Na}$ bolečino gledaš drugače, ko ni več le pojem, opisan v zakladnici knjig, člankov ipd., ampak jo povežeš z izkušnjami - vsemi izkušnjami, ki jih pridobiš med vsakodnevnim doživljanjem tako lastnega občutka kot občutka drugih, kjer pa je izkušnja »posredna«, mogoča le z veliko empatije in z zaupanjem poročanju o notranjem doživljanju drugih. Potrebno jim je verjeti, saj je njihovo bolečino mogoče »spoznati« le s sledenjem njihovemu zavestnemu ali nezavednemu poročanju. To je odvisno od niza notranjih in zunanjih vplivov, ki so lahko tudi povezani, in število možnih različnih odzivov je nemogoče določiti. Več ko imamo znanja, bolj znamo spoštovati posameznike, ki z bolečino živijo, njihove spremljevalce $v$ ožjem in širšem socialnem krogu ter strokovnjake, ki se trudijo izbrati najboljšo in najučinkovitejšo pomoč.

Bolečina prepleta življenje tako posameznika kot družbe. Po eni strani omogoča preživetje, po drugi pa kot razlog za stisko, ki jo je povečini možno obvladati, kaže razvitost in povezanost sociokulturnih skupnosti. Naše delo sega na različna področja; predstavitev izzivov, ki so skupni Slovencem v matični domovini in drugod, bo ena prihodnjih pomembnejših nalog.

Literatura

Ahmed, Mohamed Nooman, Andeep S. Toor, Kelsey O'Neil and Dawson Friedland. 2017. Cognitive computing in the future of health care: the cognitive power of IBM Watson has the potential to transform global personalized medicine. IEEE pulse 8 (3): 4-9.

Arendt-Nielsen, Lars, Bart Morlion, S. Perrot, A. Dahan, A. Dickenson, H. G. Kress, C. Wells, D. Bouhassira and A. Mohr Drewes. 2018. Assessment in manifestation of central sensitisation across different chronic pain conditions. European Journal of Pain 22 (2): 216-241.

Basbaum, Allan I. and M. Catherine Bushnell. 2008. Science of pain. Amsterdam: Academic.

Basbaum, Allan I. and Thomas M. Jessell. 2014. »Pain«. V Principles of neural science, eds. Eric R. Kandel, James H. Schwartz, Thomas M. Jessell, Steven A. Siegelbaum and A. James Hudspeth, 530-555. New York : McGrawHill Medical.

Berghaus, Goran and Tit Albreht. 2020. Uporaba komplementarnih in alternativnih metod zdravljenja $v$ zdravniški praksi v Sloveniji. Isis : glasilo Zdravniške zbornice Slovenije 29 (5): 30-33. 


\section{Meh, D. Georgiev \\ Bolečina kot pojav, razpet med telo, ...}

Bonica, John J. 1991. History of pain concepts in pain therapy. The Mount Sinai journal of medicine, New York 58 (3): 191-202.

Breivik, Harald, Beverly Collett, Vittorio Ventafridda, Rob Cohen and Derek Gallacher. 2006. Survey of chronic pain in Europe: prevalence, impact on daily life, in treatment. European journal of pain 10 (4): 287-333.

Chen, Jun. 2011. History of pain theories. Neuroscience bulletin 27 (5): 343-350.

Černivec, Manca, Dejan Gabrovšek, Nataša Gliha Komac, Nataša Jakop, Janoš Ježovnik, Boris Kern, Simona Klemenčič, Domen Krvina, Nina Ledinek in Matej Meterc. 2020. Slovar slovenskega knjižnega jezika. Ljubljana: Založba ZRC.

Delo. 2020. V Tabascu odkrili najstarejše majevsko svetišče. Delo, 04. junij 2020. https://www.delo.si/novice/svet/v-tabascu-odkrili-najstarejso -majevsko-piramido/

Descartes, René. 1972. Treatise of man. Cambridge: Harvard University Press.

Dnevnik. 2018. Arheolog Ivan Šprajc predstavil novo sezono raziskav na območju Majev na Jukatanu. Dnevnik, 11. oktober 2018. https://www. dnevnik.si/1042842954

El-Ansary, M. M. 1989. History of pain relief by ancient Egyptians. Middle East journal of anaesthesiology 10 (2): 99-105.

Fricker, Janet. 2003. Pain in Europe - A 2003 report. Cambridge, England: Mundipharma International Limited.

Gaskin, Darrell J. and Patrick Richard. 2011. Appendix C: The economic costs of pain in the United States. Relieving Pain in America: A Blueprint for Transforming Prevention, Care, Education, in Research: 1-22.

Gaskin, Darrell J. and Patrick Richard. 2012. The economic costs of pain in the United States. The Journal of Pain 13 (8): 715-724.

Gatchel, Robert J., Yuan Bo Peng, Madelon L. Peters, Perry N. Fuchs and Dennis C. Turk. 2007. The biopsychosocial approach to chronic pain: scientific advances in future directions. Psychological bulletin 133 (4): 581-624.

Haggard, Patrick, Gian Domenico lannetti and Matthew R Longo. 2013. Spatial sensory organization in body representation in pain perception. Current Biology 23 (4): R164-R176.

Halioua, Bruno and Bernard Ziskind. 2005. Medicine in the Days of the Pharaohs. Cambridge: Belknap Press of Harvard University Press.

Hu, Xiao-Su, Thiago D. Nascimento, Mary C. Bender, Theodore Hall, Sean Petty, Stephanie O'Malley, Roger P. Ellwood, Niko Kaciroti, Eric Maslowski and Alexandre F. DaSilva. 2019. Feasibility of a Real-Time Clinical Augmented Reality in Artificial Intelligence Framework for Pain Detection in Localization From the Brain. Journal of medical Internet research 21 (6): e13594.

Iannetti, G. D. and A Mouraux. 2010. From the neuromatrix to the pain matrix (and back). Experimental brain research, no. 205:1-12.

Large, Robert G. 1996. Psychological aspects of pain. Annals of the rheumatic diseases 55 (6): 340-345. 
Leadley, R.M.,N.Armstrong,Y.C.Lee,A.Allen andJ.Kleijnen.2012.Chronic diseases in the European Union: the prevalence in health cost implications of chronic pain. Journal of pain \& palliative care pharmacotherapy 26 (4): 310-325.

Li, Kun, Jinguo Wang and Na Wang. 2019. Research on intelligent management of pain. IOP Conference Series: Materials Science in Engineering.

Loeser, John D. and Rolf-Detlef Treede. 2008. The Kyoto protocol of IASP basic pain terminology. Pain 137: 473--477.

McGrath, P. A. 1994. Psychological aspects of pain perception. Archives of oral biology 39: S55S-S62.

Meh, Duška in Dejan Georgiev. 2013. Osnove zaznavanja, dojemanja (spoznavanja) in prepoznavanja bolečine = Principles of pain sensation, perception in recognition. Medicinski razgledi 52: 105-118.

Meh, Duska, Kaja Meh in Dejan Georgiev. 2016a. Cognitive interpretation of instrumentally assessed pain reports. Ljubljana: Kognitivna znanost.

Meh, Duška, Kaja Meh in Dejan Georgiev. 2016b. Psihofizikalne preiskave pri celostni obravnavi bolečine. Psihološka obzorja 25: 190.

Meh, Duška, Dejan Georgiev and Kaja Meh. 2017. Cognitive modulation of pain: how do cognition/mind influence pain processing? Ljubljana: Kognitivna znanost.

Meh, Duška in Dejan Georgiev. 2019. Prepričanja in miti o bolečini. Mavrica aktivnega življenja 30: 19-21.

Meh, Duška, Dejan Georgiev and Metod Meh. 2019. Artificial intelligence in pain: a promising future. Ljubljana: Kognitivna znanost.

Meh, Duska in Dejan Georgiev. 2021. Neobjavljeno delo.

Melzack, Ronald and Patrick D. Wall.1962. On the nature of cutaneous sensory mechanisms. Brain 85 (2): 331-356.

Melzack, Ronald and Patrick D. Wall. 1965. Pain mechanisms: a new theory. Science 150 (3699): 971-979.

Melzack, Ronald and W. S. Torgerson. 1971. On the language of pain. Anesthesiology 34: 50-9.

Melzack, Ronald. 1993. Pain: past, present in future. Canadian Journal of Experimental Psychology/Revue canadienne de psychologie expérimentale 47 (4): 615-629.

Melzack, Ronald. 1996. Gate control theory. Pain Forum 5: 128-138.

Melzack, Ronald.1999. From the gate to the neuromatrix. Pain Suppl 6:S121-6.

Melzack, Ronald. 2001. Pain in the neuromatrix in the brain. Journal of dental education 65 (12): 1378-1382.

Melzack, Ronald. 2005. Evolution of the neuromatrix theory of pain. The Prithvi Raj Lecture: presented at the third World Congress of World Institute of Pain, Barcelona 2004. Pain practice 5: 85-94.

Merskey, Harold and Nikolai Bogduk, eds. 2012. Classification of Chronic Pain. Descriptions of Chronic Pain Syndromes in Definitions of Pain Terms. Second ed, IASP Press. Seattle: IASP Press. 
Merskey, Harold, Ulf Lindblom, James M. Mumford, Peter W. Nathan and Sydney Sir Sunderland. 2012. „Pain terms: a current list with definitions in notes on usage". In Classification of chronic pain: descriptions of chronic pain syndromes in definitions of pain terms, editors Harold Merskey and Nikolai Bogduk, 210-13. Seattle: IASP Press.

Moravec Berger, Daša in Irena Kovačič. 2005. Mednarodna klasifikacija bolezni in sorodnih zdravstvenih problemov za statistične namene: MKB-10: deseta revizija. 2. izdaja. Ljubljana: Inštitut za varovanje zdravja Republike Slovenije.

Moriarty, Orla and David P. Finn. 2014. Cognition in pain. Current opinion in supportive in palliative care 8: 130-136.

Moseley, Lorimer G., David S. Butler, Timothy B. Beames and Thomas J. Giles. 2012. The graded motor imagery handbook. Adelaide: Noigroup publications.

Perl, Edward R. 2007. Ideas about pain, a historical view. Nature Reviews Neuroscience 8 (1): 71-80.

Pirc,Jelka in Marija Cesar Komar. 2007. Prevalenca kronične bolečine v Sloveniji. Isis - Glasilo zdravniške zbornice slovenije 6: 43-44.

Pombo, Nuno and Nuno M. Garcia. 2019. „Towards Pain-Fingerprinting: A Ubiquitous in Interoperable Clinical Decision Support System for Pain Assessment“. International Conference on Medical in Biological Engineering.

Price, Donald D. and James J. Barrell. 2012. Inner experience in neuroscience: merging both perspectives. Cambridge: MIT Press.

Price, Donald D. and M. Catherine Bushnell, eds. 2004. Psychological methods of pain control : basic science in clinical perspectives. Vol. 29. Seattle: IASP Press.

Qureshi, Naseem Akhtar, Gazzaffi Ibrahim Ali, Tamer Shaban Abushanab, Ahmed Tawfik El-Olemy, Meshari Saleh Alqaed, Ibrahim S El-Subai and Abdullah M.N. Al-Bedah. 2017. History of cupping (Hijama): a narrative review of literature. Journal of integrative medicine 15 (3): 172-181.

Rey, Roselyne, Louise Elliott Wallace, J. A. Cadden, S.W. Cadden and Gert H. Brieger. 1995. The history of pain. Cambridge: Harvard University Press.

Rodegra,H.and H.W.Schreiber. 2002.,,Schmerz im Paradigmawandel der Medizin Geschichte des Schmerzes-Philosophie-Kultur-Weltanschauung“. In Anästhesiologie: 429 Tabellen, editors Jens-Rainer Allenberg and HansAnton Adams, 3-7. Stuttgart: Georg Thieme Verlag.

Schleifer, Ronald. 2014. Pain in suffering. New York: Routledge.

Schulkin, Jay, ed. 2004. Allostasis, homeostasis, in the costs of physiological adaptation. Cambridge: Cambridge University Press.

Simons, Laura E., Igor Elman and David Borsook. 2014. Psychological processing in chronic pain: a neural systems approach. Neuroscience \& Biobehavioral Reviews 39: 61-78.

Topol, Eric J. 2019. High-performance medicine: the convergence of human in artificial intelligence. Nature medicine 25 (1): 44. 
Uddin, Lucina Q. 2015. Salience processing in insular cortical function in dysfunction. Nature reviews neuroscience 16 (1): 55-61.

Veith, Ilza. 2015. The yellow emperor's classic of internal medicine. Berkeley: University Of California Press.

Zhu, Ming. 2005. The medical classic of the yellow emperor. Beijing: Foreign Languages Press.

\author{
Duška Meh \\ Univerzitet u Ljubljani \\ Medicinski fakultet \\ Slovenija \\ meh.duska@gmail.com \\ Dejan Georgiev \\ Univerzitet u Ljubljani \\ Filozofski fakultet \\ Slovenija \\ dejan.georgiev@gmail.com
}

\title{
BOL KAO POJAVA, RAZAPETA IZMEĐU TELA, DUHOVNOSTI I SOCIOKULTURNOG OKRUŽENJA
}

Bol je višedimenzionalni fenomen. Možemo ga razumeti ako uzmemo u obzir niz faktora koji na njega utiču, prepliću se i međusobno sarađuju, te zajedno stvaraju jedinstveni osećaj, koji svako od nas doživljava na svoj način. Bol je, naime, lično iskustvo koje ne možemo da podelimo, ali možemo glasovima, rečima, gestovima i ponašanjem da ga pokažemo drugima. Sa puno empatije, oni ga mogu bar okvirno upoznati i razumeti. S obzirom na to da se bol javlja u različitim istorijskim i sociokulturnim sredinama, njegovo opažanje je raznoliko i zavisi od niza faktora. Bol ne utiče samo na pojedinca koji ga oseća već i na porodicu, rođake i društvo u celini.

Ključne reči: bol, kulturološke razlike, psihosocijalni faktori, telo 


\author{
Duška Meh \\ University of Ljubljana \\ Faculty of Medicine \\ Slovenia \\ meh.duska@gmail.com \\ Dejan Georgiev \\ University of Ljubljana \\ Faculty of Philosophy \\ Slovenia \\ dejan.georgiev@gmail.com
}

\title{
PAIN AS A PHENOMENON, SUSPENDED BETWEEN THE BODY, SPIRITUALITY AND THE SOCIO-CULTURAL ENVIRONMENT
}

Pain is a multidimensional phenomenon. One can comprehend it taking into account a number of factors that affect it, intertwine and collaborate with each other, and jointly create a unique feeling, which each individual experiences in their own way. Namely, pain is a personal experience that one cannot share, but can show it to the other people by means of voices, words, gestures and behaviour. If others involve a lot of empathy, they can at least become aware of it and understand it. Since pain occurs in different historical and socio-cultural environments, its perception is diverse and it depends on a number of factors. Pain affects not only the individual who feels it but also the family, relatives and society as a whole.

Keywords: pain, cultural differences, psychosocial factors, body

Primljeno / Prejeto: 07. 06. 2020.

Prihvaćeno / Sprejeto: 04. 12. 2020. 